\title{
An analysis of the Strategies of Social Service Agency, Women's Empowerment and Child Protection in Reducing Domestic Violence in Banjar City (A Case Study on Women's Empowerment and Child Protection)
}

\author{
$1^{\text {st }}$ Nova Chalimah Girsang \\ Department of Government Science \\ STISIP Bina Putera Banjar \\ Banjar City 46311, Indonesia \\ nova.chalimah.girsang@stisipbp.ac.id \\ $4^{\text {th }}$ Achmad Daryatno \\ Department of Government Science \\ STISIP Bina Putera Banjar \\ Banjar City 46311, Indonesia
}

\author{
$2^{\text {nd }}$ Tofan Ibrahim \\ Department of Government Science \\ STISIP Bina Putera Banjar \\ Banjar City 46311, Indonesia \\ $5^{\text {th }}$ Anis Sundari \\ Department of Government Science \\ STISIP Bina Putera Banjar \\ Banjar City 46311, Indonesia
}

\author{
$3^{\text {rd }}$ Mira Andriani \\ Department of Government Science \\ STISIP Bina Putera Banjar \\ Banjar City 46311, Indonesia
}

\begin{abstract}
This present study utilized a descriptive qualitative approach. The data were collected through indepth interviews conducted to the informants continuously until the data were saturated. The results of the recorded data were thoroughly transcribed. The data were then grouped according to the stages of implementation. The results indicated that the main factors causing domestic violence are the economic factor, and the third person factor. Meanwhile, the efforts done by the agency, in collaboration with PKK (Family Welfare Development), to decrease the domestic violence rate was by conducting monthly socialization and positive activities to help restore the mental health of the victims of the domestic violence. It was conducted by providing the psychiatrists and advocates for the victims and the reporters of domestic violence in Banjar City.
\end{abstract} Child

Keywords-Social Service Agency, Women Empowerment,

\section{INTRODUCTION}

The state guarantees security, equality and justice for every citizen stated in article 28 paragraph (1) of the 1945 Constitution that "every person has the right to protection of personal, family, honor, dignity and protection from the threat of equality and justice". However, violence often happens. It is actually done by people in the environment around us. One example is the family[1].

Athough wise, violence against woman, are suffering to woman make it against phycis dan physic[2]. Women's empowerment is a systematic and planned effort to achieve gender equality and justice in family and community life. Empowerment of women as human resources, the potential of women in terms of quantity and quality are not below men[3]. However, in reality, it is still found that women status in society is still subordinate and she is not as equal partner as men. In addition, there are many realities that develop in society where there are discriminatory attitudes and actions towards women as a lower sex than men, resulting that women have development obstacles in various fields of life and even threaten their lives. One of the examples is act of domestic violence against women[4].

The purpose of the development of women's empowerment is to improve the status, position and condition of women in order to achieve equal progress with men, to build Indonesian children to be healthy, intelligent, cheerful and devoted and well protected[5].

Law Number 4 of 1979 concerning Child Welfare as a whole regulates children, especially in the field of welfare. There are several articles dealing with children in relation to the protection of children in the family, even though it is indirect. It is relating to children who experience acts of domestic violence. Indonesia have regulation to rule Violence against woman, etc Law numer twenty three year two thousand and four. That regulation is approve about Reconstructing Gender Empowerment[6].

Based on data from the Indonesian Child Protection Commission (KPAI), in 2014 there were 656 cases (Kompas.16 Dec,2017).In 2015 the number increased by 
9\% from 2014 amounting to 321,752, which mostly came from case data or the case handled by the Religion Courts (CNN.7 March.2017). In 2016, KPAI received 3,581 cases of public complaints. Of that number, 414 cases were cyber based children crime (Kompas, 17 March,2017). Whereas data on domestic violence (KDRT) of the Indonesian Women's National Commission revealed that there were 259,150 cases of violence against women during 2016, compiled from data in the Religion Court and handled by partner service provider in Indonesia. The National Women's Commission divides it into violence in the realm of personal, community and state domain. In the realm of personal / household or domestic violence, the highest violence is violence against wives of 5,784 cases, and violence in courtship or KDP reached 2,171 cases, cases of violence against girls 1,799 cases, the others are violence committed by ex-husband, ex-boyfriend and against household maid.

Upon that data, shows that violence against woman more increase in several city. Proven that need more protection for woman in their lives. Cause woman in special individu, although theiir householdmaid[7].

The purpose of this research is to find out the strategy of Social Service Agency, Women's Empowerment and Child Protection strategy in reducing the number of domestic violence in Banjar city, and to find out the effort and obstacle in reducing the number of domestic violence (KDRT) in Banjar City.

\section{LITERATURE REVIEW}

Strategy is a tactic / way that is relatively simple and easy to understand, namely, Corporate strategy, Strategy Program, Resource Support Strategy, Institutional strategy. In the process of reducing the number of domestic violence in Banjar City to achieve a better direction in the future, certain strategies are required to achieve this goal[8].

According to Sharon G. Portwood and Julia Finkel Heany, "The strategy in handling domestic violence requires a social approach to the family", International Journal of Responding to Violence against Women: Social Science Contributions to Legal Solutions[9].

In the article of Kimberly A.Svevo-Cianci, The New UN CRC General Comment 13: "The Right of Child to
Freedom from All Forms of Violence"-Changing How the World Conceptualizes Child Protection, explained that underage marriage is one of the reasons causing Domestic Violence[10].

The writer of Song ul Salla Gul in her article entitled The Role of State in Protecting Women against Domestic Violence a Women's Shelters in Turkey, reveled her research finding as follows:

1. International law influences national law in Turkey, which regulates domestic violence;

2. Family law regulation in Turkey is having a shift;

3. Domestic violence case in Turkey is still considered privacy[11].

Also explain, that Violence in The Family, can make victim in trouma, so they have to recovery they psychology[12].The government, must be understanding the violence's victim, make sure that they in right hand and more comfortable[13].

Violence against women, in every case, is different methods in development countries. The violence against women, not just the woman, became the victim, but also, they child, they parents, could became the victim too[14].

\section{A. Type of Research}

\section{METHODS}

The type of research used descriptive analysis research. Descriptive research method is a research method conducted to determine the value of independent variables or more (independent) without making comparisons between one variable with another[15].

\section{B. Informant determination technique}

The selection of informant on the research on Social Service Agency Strategy, Women's Empowerment and Child Protection in this study used snowball sampling techniques. Kanto stated that the snow ball sampling technique involves three stages: first, selecting the initial sample to be interviewed, second, selecting the next sample to widen the information description and third, stopping the selection of that next sample if replication of the information is obtained. The use of this technique always has certain considerations[16]. First, the research must know the knowledge about certain characteristics obtained from the previous population. Informants in this study are as follows:

TABLE I. LIST OF INFORMAN

\begin{tabular}{|l|l|l|l|}
\hline No & \multicolumn{1}{|c|}{ Sample } & \multicolumn{1}{|c|}{ Name } & Number \\
\hline 1. & $\begin{array}{l}\text { The head of Social Service Agency, Women's } \\
\text { Empowerment and Child Protection }\end{array}$ & Drs. H. Tatang Iskandar & 1 Person \\
\hline 2. & $\begin{array}{l}\text { The Section Head of Women's Empowerment and } \\
\text { Child Protection }\end{array}$ & Hj.Ika Kartikawati S.IP, M.Si, & 1 Person \\
\hline 3. & $\begin{array}{l}\text { The Administration Staff of Women's } \\
\text { Empowerment and Child Protection }\end{array}$ & Idan & 1 Person \\
\hline 4. & Law Practitioner & Lela Siti Nur Aladin,SH & 1 Person \\
\hline 5. & Family Welfare Development (PKK) & $\begin{array}{l}\text { 1. Ilah } \\
\text { 2. Nia }\end{array}$ & 2 Person \\
\hline 6. & Victim of Domestic Violence case in 2016 & $\begin{array}{l}\text { 1. Iya } \\
\text { 2. Bunga } \\
\text { 3. Mawar }\end{array}$ & 3 Person \\
\hline & Total Number & & 9 Person \\
\hline
\end{tabular}


Data collection technique is the most strategic step in the research, because the main objective of the researcher is to obtain data. Without knowing data collection techniques, the researcher will not get data that meet the standardized data[17]. Based on this theory, the data collection technique used in this study consists of:

- Literature review

- Field study

Data collection technique is conducted by means of direct interviews with competent parties and research objects. Making observation is also conducted.

- Observations according to Nasution (pp.44.2001)

- Observation is the basis of all sciences. Scientists can only work based on data, namely facts about the world of reality obtained through observation.

- Interview according to Sugiyono (pp.231.2010)

- An interview is a meeting of two people to exchange information and ideas through questions and answers, so that meaning can be constructed in a particular topic.

\section{Processing Technique and Data Analysis}

After everything is collected, in writing the data obtained both primary and secondary data, then the data is processed and analyzed in descriptive qualitative technique using law and case approach as well as interpreted based on theory while answering this writing or research problems. The followings are some steps of qualitative analysis according to Sugiyono (pp.245.2010):

- Analysis before going to the field. It is conducted before the researcher enters the field. The analysis is carried out on the result of the preliminary study, or secondary data that will be used to determine the focus of the study.

- Data analysis in the field. It is carried out at the time the data collection takes place, and after the data collection is completed within a certain period.

Furthermore, Miles and Hubermen[18] provide a model of data analysis in the field as follows:

- Data Reduction

- Data Display

- Conclusion drawing/verification

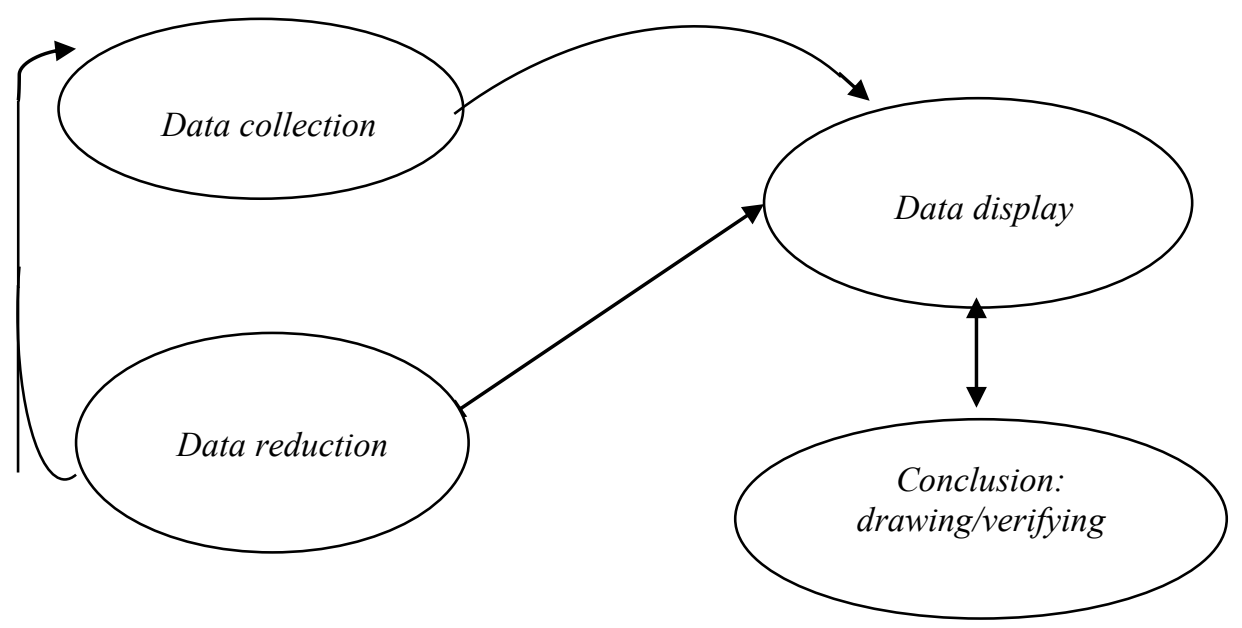

Fig. 1. Data Analysis Model

\section{RESULT AND DISCUSSION}

A. Strategy analysis of Social Service Agency, Women's Empowerment and Child Protection in reducing the rate of Domestic Violence in Banjar city

The approach used is the one of Strategy Theorists from Kooten (Salusu.pp.104.2006), namely: Corporate strategy, Program strategy, Resource Support Strategy, Institutional strategy.

Social Service Agency, Women Empowerment and Child Protection in Banjar City is one of the development of institutions to provide services for women empowerment, prevention of violence against women, provision of services for women and children victims of violence, strengthening and development of institutions for protection of women and children, improving the quality of families in realizing mainstreaming Gender / Gender Health (KG) and enhancing the rights of women and children, coordinating the formulation of policies and technical guidelines in the Field of Women's Empowerment and Child Protection in Banjar City.

Social Service Agency, Women's Empowerment and Child Protection has a position as the provision of facilitator services for victims of violence and victims of human trafficking and it doesn't follow up complaints related to the law. The target to be achieved is to reduce the number of domestic violence in Banjar City. Social Service Agency for Women Empowerment and Child Protection has the task of verifying the choice of violence prevention services involving social organizations, verifying the data collection of victims in a disaggregated manner and coordinating the provision of facilities for Human Resources (HR) in handling victims of violence and victims of human trafficking.

B. Barriers to Social Service Agency, Women's Empowerment and Child Protection in reducing the number of domestic violence in Banjar city 
Limitations in the achievement of information dissemination to the community and victims of domestic violence become obstacles to Social Service Agency, Women's Empowerment and Child Protection of Banjar city.

The obstacles faced by Social Service Agency, Women's Empowerment and Child Protection in reducing the number of domestic violence in Banjar City are:

The community has lack of understanding on the function of marriage and family, the existence of underage marriage which triggers quarrels and violence in the household and many people in Banjar City are reluctant to report acts of domestic violence (KDRT) to Social Service Agency, Women's Empowerment and Child Protection in Banjar city.

C. Some efforts conducted by Social Service Agency, Women's Empowerment and Child Protection to reduce the rate of Domestic Violence in Banjar City

- Implementing coordination with community institutions such as the institution of Family Welfare Development (PKK) by having socialization activities in the local of Banjar City area.

- Running programs as:

- The program of Consultation Corner from the institution of Family Welfare Development (PKK) which is beneficial for victims of Domestic Violence (KDRT) who have physic and mental disorder;

- Facilitating human resource or companion for victims who make the report

- Providing psychiatrist from the Department of Health in collaboration with Social Service Agency, Women's Empowerment and Child Protection in Banjar City;

- Carrying out peaceful effort against those who get involved domestic violence case;

- Conducting information dissemination related to the distribution of information on the Law Number 23 of 2004 concerning the Elimination of Domestic Violence.

\section{CONCLUSION}

Social Service Agency for Women Empowerment and Child Protection of Banjar city, which is positioned as the provision of facilitator services for victims of domestic violence (KDRT), has been proven to participate actively in reducing the number of domestic violence in Banjar city with 5 program mainly.

\section{REFERENCES}

[1] Y. F. Wismayanti, P. O’Leary, C. Tilbury, and Y. Tjoe, "Child sexual abuse in Indonesia: A systematic review of literature, law and policy," Child Abuse Negl., vol. 95, p. 104034, 2019

[2] M. H. Soeroso, Kekerasan Dalam Rumah Tangga. Jakarta: Sinar Grafika, 2010

[3] T. Prenzler and L. Fardell, "Situational prevention of domestic violence: A review of security-based programs," Aggress. Violent Behav., vol. 34, pp. 51-58, 2017.

[4] L. L. Heise, A. Raikes, C. H. Watts, and A. B. Zwi, "Violence against women: a neglected public health issue in less developed countries," Soc. Sci. Med., vol. 39, no. 9, pp. 11651179, 1994.

[5] Q. W. Xie, X. Sun, M. Chen, D. P. Qiao, and K. L. Chan, "What prevents Chinese parents from reporting possible cases of child sexual abuse to authority? A holistic-interactionistic approach," Child Abuse Negl., vol. 64, pp. 19-31, 2017.

[6] J. Syed, "Reconstructing gender empowerment," in Women's Studies International Forum, 2010, vol. 33, no. 3, pp. 283-294.

[7] A. Gosita, Korban Kekerasan Dalam Rumah Tangga, Hak dan Kewajiban Korban Kekerasan Dalam Rumah Tangga. Jakarta: Rafika Adika, 1993

[8] I. Rindaningsih, "Pengembangan Model Manajemen Strategik Berbasis (beyond center and circle Time) bect Pada Paud," Pedagog. J. Pendidik., vol. 1, no. 2, pp. 213-223, 2012.

[9] S. G. Portwood and J. F. Heany, "Responding to violence against women: Social science contributions to legal solutions," Int. J. Law Psychiatry, vol. 30, no. 3, pp. 237-247, 2007.

[10] K. A. Svevo-Cianci, M. Herczog, L. Krappmann, and P. Cook, "The new UN CRC General Comment 13:'The right of the child to freedom from all forms of violence'-Changing how the world conceptualizes child protection," Child Abuse Negl., vol. 35, no. 12, pp. 979-989, 2011.

[11] S. S. Gül, "The role of the state in protecting women against domestic violence and women's shelters in Turkey," in Women's Studies International Forum, 2013, vol. 38, pp. 107116

[12] D. K. Gosselin, Heavy hands: An introduction to the crimes of family violence. Prentice Hall Boston, MA, 2010.

[13] S. K. Wurtele, "Understanding and preventing the sexual exploitation of youth," 2017.

[14] L. R. Kurtz and J. Turpin, Encyclopedia of violence, peace, and conflict, vol. 1. Academic Press, 1999.

[15] E. Barlian, Metodologi Penelitian Kualitatif \& Kuantitatif. INARxiv, 2018.

[16] K. Bungin, Metode Penelitian Kualitatif dan Kuantitatif. Jakarta, 2003.

[17] Akdon, Strategic Manajement For Education Manajement. Bandung: Alfabeta, 2011.

[18] A. M. Hubberman and M. B. Miles, "Qualitative data analysis," Beverly Hills Sage, 1994. 